\title{
PELATIHAN MENGAPLIKASIKAN GMAIL DAN YMAIL UNTUK CALON GURU SEKOLAH DASAR
}

Bayu Purbha Sakti

Universitas Widya Dharma Klaten

bayups@unwidha.ac.id

Submited : 6 Agustus 2020

Acepted : 12 Agustus 2020

Published : Desember 2020

\begin{abstract}
Abstrak
Guru sekolah dasar dituntut supaya bisa menggunakan email. Mahasiswa calon guru sekolah dasar sekarang harus bisa menguasai email untuk mengajarkannya pada generasi masa depan. Kegiatan pengabdian ini bertujuan untuk memberikan pelatihan dan keterampilan pada mahasiswa Program Studi Pendidikan Guru Sekolah Dasar Universitas Widya Dharma Klaten. Para peserta kegiatan pelatihan mulai menyadari bahwa mereka dapat mengirim pesan menggunakan Gmail dan ymail, bisa bertanya secara langsung pada waktu itu juga menggunakan Gmail dan ymail, dan menyimpan artikel ketikan menggunakan Gmail dan ymail. Semua peserta yang mengikuti kegiatan pelatihan sangat memiliki minat untuk menjadi guru sekolah dasar sehingga perlu memiliki email karena nantinya sebagai guru sekolah dasar, mereka dapat berkomunikasi melalui email, mengirimkan silabus, dan menggunakannya menjadi data akun yang diakui dinas pendidikan.
\end{abstract}

Kata Kunci : Guru Sekolah Dasar, Gmail, Ymail, Kegiatan Pelatihan 


\section{PENDAHULUAN}

Pada zaman sekarang email sudah sering digunakan. Guru sekolah dasar dituntut supaya bisa menggunakan email. Mahasiswa Program Studi Pendidikan Guru Sekolah Dasar adalah calon guru sekolah dasar yang sangat diandalkan pada zaman sekarang. Mahasiswa calon guru sekolah dasar sekarang harus bisa menguasai email untuk mengajarkannya pada generasi masa depan.

Layanan pesan elektronik atau yang biasa dikenal email sangat membantu mahasiswa dalam melakukan semua kegiatan yang bisa menjangkau belahan dunia. Layanan email juga bisa membantu masyarakat atau semua orang untuk mendapatkan berbagai informasi. Layanan email juga dapat mengecek kebenaran berita dan penulisannya. Masalah para mahasiswa memiliki kemampuan dasar untuk menulis dan memahami sebuah penulisan berita tidak salah karena penyebaran berita hoax juga sudah tidak karu-karuan di era perkembangan informasi seperti ini (Susanto, 2018). Oleh karena itu, para mahasiswa perlu memiliki kemampuan melek informasi digital dan mengaplikasikan layanan email supaya mereka dapat mengetahui persebaran informasi digital yang belum tentu benar.

Layanan email yang bermasalah akan menyebabkan gangguan dari berbagai pihak. Kamis 5 September 2019 mendadak layanan email yahoo atau yahoo mail mengalami masalah yakni tidak bisa diakses atau down (Anonim, 2019). Layanan yahoo tidak bisa diakses untuk sementara waktu di berbagai belahan dunia. Dari peta Down Detector, gmail down dikeluhkan di Singapura, Kuala Lumpur (Malaysia), Jakarta dan Medan (Jakarta), Bangkok (Thailand), Ho Chi Minh City dan Hano (Vietnam), Shenzhen (China), Sebagian besar Jepang dan Manila (Filipina) (Roy, 2019). Meski pengguna sudah mengganti password tetapi email-email spam tetap bermunculan (Wardani, 2019). Banyak orang menanggapi masalah- masalah yang ditemui di akun gmail. Mereka juga meminta kepada pihak Google untuk menyelesaikan masalah email spam di akun gmail. Sejumlah aplikasi email seperti ymail.com dan gmail.com telah membatasi jumlah pengiriman dalam kurun waktu tertentu (Oetomo, 2009). Hal tersebut dilakukan untuk mengatasi penyebarluasan spam email. Aplikasi email-email tersebut juga akan mengembalikan tulisan file apabila alamat email yang dituju salah. Apabila file yang diterima diletakkan dalam spam maka file tersebut akan dihapus dalam waktu 24 jam.

Penggunaan email kantor adalah suatu cara untuk memperjelas alamat email, tetapi ada masalah yang ditimbulkan dari penggunaan email kantor. Tiga orang profesor di Amerika Serikat melakukan penelitian dari 297 orang dewasa yang bekerja tentang penggunaan email kantor (Sunu, 2019). Hasil penelitian penggunaan email kantor adalah ketidakmampuan pekerja untuk offline dari email kantor karena penggunaan email kantor dapat menyebabkan kelelahan kerja yang berpengaruh pada produktivitas yang buruk dan pencapaian target lebih rendah. Email kantor yang diaktifkan di ponsel akan menyebabkan 
kecemasan yang akhirnya memicu kelelahan emosional.

Permasalahan mengenai penggunaan email juga terjadi di benua eropa. Alasan berkirim pesan dan email di luar jam kerja ilegal karena Prancis mendukung hidup seimbang antara kerja dan kehidupan pribadi (Wardani, 2019). Kasus ini diberitakan terjadi di Negara Prancis. Pengiriman email ke karyawan setelah jam kerja dan pada saat akhir pekan adalah hal ilegal. Hal itu dikarenakan orang memang membutuhkan istirahat dari pekerjaan dan berkonsentrasi pada keluarga, teman-teman, dan hobi. Mereka seharusnya tidak terbebani membalas email dari rekan kerja atau atasan di luar jam kerja.

Adanya kelalaian pengiriman email akan menimbulkan masalah baru. Juru bicara maskapai British Airways mohon maaf dengan adanya email error yang beredar (Priambodo, 2019). Juru bicara maskapai mengatakan bahwa pihaknya akan terus menghubungi para calon penumpang yang sebenarnya terbang pada tanggal itu tetapi mendapat email tentang pesawat yang tidak terbang. Juru bicara maskapai memastikan penumpang lainnya tetap bisa melakukan penerbangan.

Layanan email juga dapat digunakan dalam mengisikan data pokok pendidikan. Data pokok pendidikan (dapodik) sekolah dasar (SD) di Kota Salak masih banyak yang bermasalah (Basri, 2019). Data yang diisikan sekolah dasar di Kota Salak tidak sesuai dengan kondisi kenyataan di lapangan. Hasil tersebut mengakibatkan mereka tidak bisa mengakses bantuan dari pemerintah. Pembaharuan dapodik seharusnya dapat dilakukan setiap hari.
Sosialisasi mengenai pengisian dapodik yang online sudah dilakukan di berbagai lembaga pendidikan. Keberpihakan pengisian akan menimbulkan permasalahan dalam pendataan dapodik. Isian data dapodik diharapkan tidak condong ke siswa atau condong ke guru (Susanto, 2019). Sarana dan prasarana dapat diisikan secara nyata di dapodik sangat diharapkan untuk mempermudah pemberian bantuan. Pemberitahuan mengenai data yang ada di dapodik juga harus menuju layanan email supaya para pengolah dapodik bisa mengetahuinya setiap saat.

Adanya keterbatasan yang dimiliki seseorang dalam menulis email juga akan menimbulkan masalah lainnya. Seorang guru yang belum menulis email tentunya mengundang keprihatinan. Guru kelas SDN 9 Jangka mengatakan bahwa ia mendapat kesempatan untuk membuat tulisan, tulisan hasil karya dikirim melalui email (Idris, 2019). Tulisan yang dikirim berbentuk tulisan tangan tentang perlindungan guru. Apabila tulisan tersebut ditulis menggunakan media komputer maka hasil yang diperoleh akan menjadi jauh lebih baik.

Mahasiswa-mahasiswi Program Studi Pendidikan Guru Sekolah Dasar (PGSD) Universitas Widya Dharma diharapkan memiliki wawasan dan pengetahuan dalam mengaplikasikan gmail dan ymail. Hal tersebut dilakukan supaya para mahasiswa dapat menguasai dan menjalankan berbagai hal yang dapat dipermasalahkan dengan email apabila mereka sudah menjadi guru. Kegiatan mengaplikasikan gmail dan ymail akan 
membiasakan para mahasiswa PGSD dalam kegiatan menulis dan mencari referensi yang nantinya mereka juga tidak kesulitan dalam mengerjakan skripsi.

Kegiatan pengabdian ini bertujuan untuk memberikan pelatihan dan keterampilan pada mahasiswa Program Studi Pendidikan Guru Sekolah Dasar Universitas Widya Dharma Klaten. Oleh karena itu, para mahasiswa tersebut diharapkan mampu menggali dan menemukan kreativitas dalam mengaplikasikan gmail dan ymail. Pekerjaan guru sekolah dasar pada jaman sekarang dituntut supaya bisa melakukan kegiatan yang berkaitan dengan gmail dan ymail. Oleh karena itu, para guru sekolah dasar nantinya sudah terbiasa dan menjadi ahli dalam mengajar yang menggunakan gmail dan ymail.

\section{TINJAUAN PUSTAKA}

Adapun kajian teori dalam penelitian ini menjelaskan tentang penggunaan email dan peran guru di sekolah dasar. Kedua hal tersebut dibahas dalam sub bab selanjutnya.

\section{Penggunaan email}

Email adalah surat dalam bentuk elektronik yang merupakan salah satu layanan atau aplikasi internet yang paling banyak digunakan (Hasanah, Handoyo, \& Ruliana, 2018). Layanan email dapat digunakan dengan mudah jika seseorang mengetahui caranya. Email merupakan fasilitas yang digunakan untuk mengelola surat menyurat beserta lampirannya secara elektronik (Sutedjo \& Oetomo, 2015). Penggunaan email dalam melakukan surat menyurat dirasakan dan dipikirkan lebih praktis karena tidak menggunakan media alat tulis. Layanan surat elektronik sendiri terbagi ke dalam dua bagian layanan surat elektronik bebas (free) dan layanan surat elektronik terbatas (Hamid, 2014). Email yang berasal dari google dan yahoo dapat digunakan secara gratis. Penggunaan email group mampu membuat komunikasi ke atas, ke bawah dan horizontal dapat dilakukan lebih cepat karena oleh siapapun, kapanpun dan dimanapun (Siahaya, 2014). Penggunaan email secara grup atau kelompok dapat mempersingkat waktu untuk memberitahukan keadaan seseorang. Acara rapat pun dapat dilakukan dengan adanya pemberitahuan dari grup email.

\section{Peran Guru Sekolah Dasar}

Guru merupakan seseorang yang seharusnya dihormati karena memiliki kepedulian yang sangat tinggi terhadap keberhasilan pembelajaran di sekolah (Sakti, 2020b). Guru adalah pengajar yang harus ditaati dan ditiru dari kepribadiannya. Guru dituntut berperan aktif dalam mengembangkan pengetahuan dan memberikan contoh sikap yang baik sesuai dengan norma yang berlaku (Sakti, 2020a). Contoh baik yang diberikan seorang guru akan menciptakan karakter yang baik pula bagi siswanya. Pendidikan karakter itu mutlak diberikan oleh para guru untuk tingkat pendidikan dasar (Sakti, 2017a). Nilai kejujuran, kedisiplinan, dan tanggung jawab adalah sebagian nilai-nilai karakter yang harus dicontohkan guru sekolah dasar supayadilakukan siswanya. Siswa sekolah dasar diharapkan 
menjadi orang yang berjiwa positif dan menjaga perdamaian (Sakti, 2018a). Kegiatan kelas akan menjadi gambaran perilaku siswa sekolah dasar. Kegiatan kelas juga harus menunjukkan gambaran tentang bagaimana sebenarnya guru sekolah dasar berperilaku (Sakti, 2019a). Guru sekolah dasar memiliki fungsi dan keahlian dalam menangani anak usia sekolah dasar (Sakti, 2019b). Pendidikan sarjana calon guru sekolah dasar dalam program studi Pendidikan Guru Sekolah Dasar (PGSD) merupakan solusi untuk menciptakan guru sekolah dasar yang berkarakter. Mahasiswa PGSD diharapkan mampu menjadi model karakter yang baik di tengah masyarakat (Sakti, 2017b). Mahasiswa PGSD juga harus bisa menulis makalah sebagai bagian dari kompetensi penelitian yang menunjang kompetensi keguruannya. Mahasiswa dihadapkan menulis makalah dan karya ilmiah untuk mengembangkan potensi intelektual dan kreativitas di masa depan (Sakti, 2018b). Pembelajaran tematik bisa juga diteliti karena pembelajaran ini merupakan perihal baru di bidang pendidikan. Pembelajaran yang dilaksanakan di sekolah dasar adalah pembelajaran tematik berdasarkan Kurikulum 2013 (Sakti \& Budiyono, 2019).

\section{METODE PENGABDIAN}

Kegiatan pengabdian ini dilakukan dengan memberikan pelatihan yang disertai beberapa metode yang digunakan. Metode penyampaiannya adalah metode ceramah, diskusi, dan tanya jawab. Penulis yang bertindak sebagai narasumber memberikan ceramah tentang definisi, manfaat, dan hasil dari berlatih menggunakan gmail dan ymail. Penulis yang bertindak sebagai narasumber memberikan waktu bagi peserta pelatihan untuk berdiskusi dengan teman dekatnya. Penulis membagi para peserta menjadi beberapa kelompok untuk berdiskusi. Penulis yang bertindak sebagai narasumber memberikan waktu bagi peserta pelatihan untuk bertanya jawab dengan narasumber apabila ada kesulitan yang ditemui. Kegiatan pengabdian dilakukan pada hari Senin sampai dengan hari Rabu pada tanggal 15 sampai dengan 17 Maret 2018. Kegiatan pengabdian dilakukan dengan durasi waktu selama 15 jam. Kegiatan dimulai dari jam 08.00 s.d 13.00 WIB dengan dihadiri para peserta yaitu para mahasiswa. Kegiatan pelatihan dihadiri mahasiswa Program Studi Pendidikan Guru Sekolah Dasar Universitas Widya Dharma. Alat yang digunakan dalam kegiatan pelatihan adalah laptop dan proyektor. Para peserta kegiatan pelatihan diharuskan membawa gadget yaitu berupa smartphone atau laptop untuk berlatih mengaplikasikan gmail dan ymail.

\section{HASIL PELAKSANAAN}

Pelaksaan kegiatan melibatkan guru sekolah dasar. Profil guru sekolah sebagai mitra PKM dan hasil kegiatan akan dibahas pada sub bab selanjutnya.

\section{Profil Guru Sekolah Dasar sebagai Mitra PKM}

Guru sekolah dasar wajib memiliki pengetahuan di segala bidang dan memiliki kompetensi menangani anak usia 7 sampai dengan 12 tahun. Bidang teknologi komputer merupakan bidang penting yang harus dikuasai 
guru sekolah dasar. Pengenalan gmail dan ymail sebagai email akan menjadi modal dasar bagi guru sekolah dasar untuk mengenal serta mengaplikasikan program software yang mendukung proses pembelajaran. Para peserta yang mengikuti kegiatan pelatihan ini adalah calon guru sekolah dasar. Mereka adalah mahasiswa program studi Pendidikan Guru Sekolah Dasar angkatan 2016. Semua peserta yang mengikuti kegiatan pelatihan sangat memiliki minat untuk menjadi guru sekolah dasar. Para peserta memiliki keinginan untuk mengajarkan penggunaan teknologi pendidikan yaitu komputerisasi pendidikan yang lebih baik kepada muridnya nanti. Salah satu peserta (yaitu Cholis) juga sudah ada yang menjadi guru di sekolah dasar. Salah satu peserta (yaitu Nilam) sudah merasakan dan menyadari betapa pentingnya penggunaan gmail dan ymail sebagai email dalam mengerjakan tugas makalah sebelum nantinya ada tugas pekerjaan guru sekolah dasar yang menggunakan email. Guru sekolah dasar nantinya juga harus memiliki email untuk berkomunikasi, mengirimkan silabus, dan sebagai data akun yang diakui dinas pendidikan.

\section{Hasil Kegiatan Pelatihan}

Kegiatan pelatihan yang telah dilakukan ternyata memiliki beberapa dampak bagi para peserta. Mereka menyadari bahwa memilik email sangat penting untuk masa depan. Penggunaan gmail dan ymail sebagai email akan mendukung para peserta pelatihan dalam belajar dan mengajar. Kebutuhan teknologi pendidikan yang lebih maju akan mempermudah proses kegiatan pembelajaran di sekolah. Mendidik generasi yang lebih canggih dalam memanfaatkan email menjadi salah satu tuntutan bagian bidang teknologi.

Gmail dan ymail dapat digunakan untuk mengirim pesan. Para peserta kegiatan pelatihan mulai menyadari bahwa mereka bisa menanyakan kabar dan keadaan melalui pesan yang dikirimkan lewat inbox email. Para peserta dilatih supaya bisa mengirimkan pesan timbal balik antara gmail dan ymail mereka sendiri. Para peserta dilatih supaya bisa membuka inbox email dengan menggunakan laptop dan smartphone

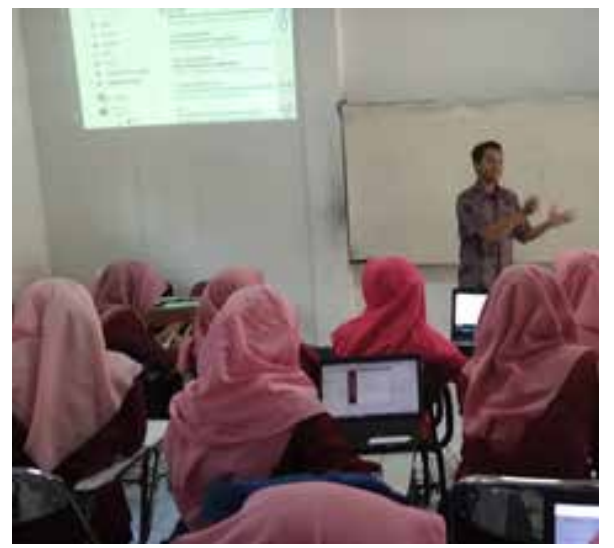

Gambar 1 penjelasan inbox email

Gmail dan ymail dapat digunakan untuk berkomunikasi langsung secara daring. Para peserta kegiatan pelatihan mulai menyadari bahwa mereka bisa bertanya secara langsung pada waktu itu juga dengan menggunakan google chat dan yahoo messenger. Para peserta dilatih supaya melakukan chat dengan narasumber maupun temannya. Para peserta dilatih supaya bisa melakukan video chat dengan menggunakan laptop. 


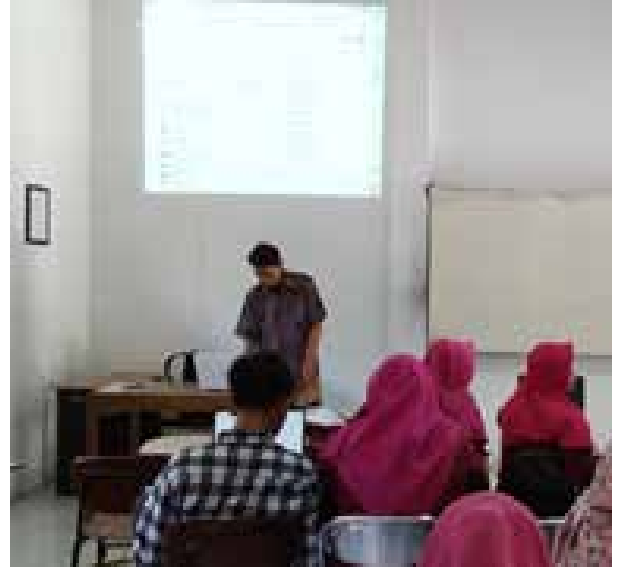

Gambar 2 pengecekan status chatting

Gmail dan ymail dapat digunakan untuk menyimpan artikel ketikan. Para peserta kegiatan pelatihan mulai menyadari bahwa mereka bisa menggunggah dan mengunduh hasil ketikan mereka supaya disimpan di folder email. Para peserta dilatih supaya bisa menyimpan artikel ketikan yang dilampirkan dengan ukuran file sebesar 2 megabyte. Ada peserta (yaitu Panji) yang mengirim file dengan ukuran $10 \mathrm{mb}$

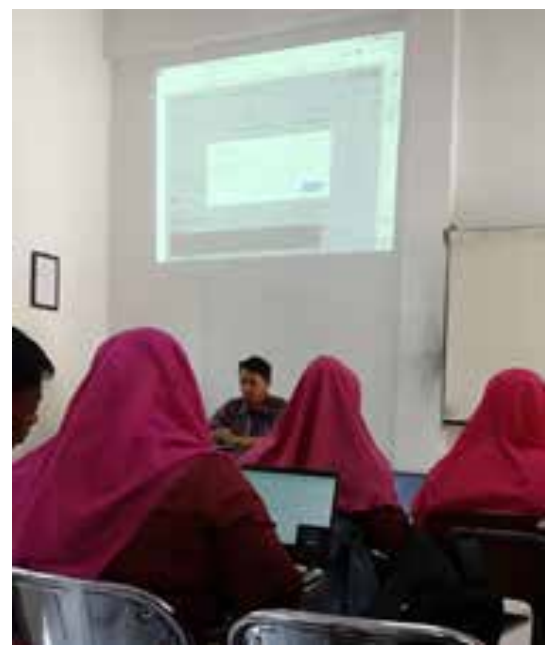

Gambar 3 pengecekan penyimpanan file

\section{KESIMPULAN}

Para peserta kegiatan pelatihan mulai menyadari bahwa mereka dapat mengirim pesan menggunakan Gmail dan ymail. Para peserta kegiatan pelatihan mulai menyadari bahwa mereka bisa bertanya secara langsung pada waktu itu juga menggunakan Gmail dan ymail. Para peserta kegiatan pelatihan mulai menyadari bahwa mereka menyimpan artikel ketikan menggunakan Gmail dan ymail. Semua peserta yang mengikuti kegiatan pelatihan sangat memiliki minat untuk menjadi guru sekolah dasar. Guru sekolah dasar nantinya juga harus memiliki email untuk berkomunikasi, mengirimkan silabus, dan sebagai data akun yang diakui dinas pendidikan.

\section{DAFTAR PUSTAKA}

Basri. (2019). Banyak Dapodik SD Bermasalah. Diambil 23 Oktober 2019, dari https://radarmadura.jawapos. com/read/2019/02/08/118359/banyakdapodik-sd-bermasalah

Hamid, H. (2014). Analisis Keamanan Aplikasi Email Pada Ponsel Android Dengan Jaringan Nirkabel. Jurnal Cybermatika, 2(1). Diambil dari http://cybermatika. stei.itb.ac.id/ojs/index.php/cybermatika/ article/view $/ 54$

Hasanah, U., Handoyo, A. H., \& Ruliana, P. (2018). Efektivitas E-Mail Sebagai Media Komunikasi Internal Terhadap. Inter Komunika: Jurnal Komunikasi, 3(2), 153-167. https://doi.org/10.33376/ ik.v3i2.233 
Idris. (2019). Fitriyanti, Guru Honorer SD 9 Jangka Diundang Workshop ke Bogor - Serambi Indonesia. Diambil 21 Oktober 2019, dari https://aceh. tribunnews.com/2019/10/21/fitriyantiguru-honorer-sd-9-jangka-diundangworkshop-ke-bogor

Priambodo. (2019). Salah Kirim Email, Maskapai Ini Bikin Panik Calon Penumpang Pesawat. Diambil 21 Oktober 2019, dari https://www.suara. com/news/2019/08/30/143735/salahkirim-email-maskapai-ini-bikin-panikcalon-penumpang-pesawat

Sakti, B. P. (2017a). Indikator Pengembangan Karakter Siswa Sekolah Dasar. Magistra Unwidha Klaten, 30, 1. https://doi.org/10.31227/osf.io/pucw9

Sakti, B. P. (2017b). Persepsi Mahasiswa Program Studi Pendidikan Guru Sekolah Dasar Universitas Widya Dharma Tentang Etika Mahasiswa. Premiere Educandum: Jurnal Pendidikan Dasar dan Pembelajaran, 7(02), 135. https://doi.org/10.25273/ pe.v7i2.1732

Sakti, B. P. (2018a). Feasibility Indicators Of Study Books Used Elementary School Students. Social, Humanities, and Educational Studies (SHEs): Conference Series. https://doi. org/10.31227/OSF.IO/5NJVK

Sakti, B. P. (2018b). Training of Scientific Papers Writing On Students of Widya Dharma University. CARADDE: Jurnal Pengabdian Kepada Masyarakat. https://doi.org/10.31960/caradde. v1i1.3
Sakti, B. P. (2019a). Student Profile Toword Course Activities At PGSD FKIP University Widya Dharma Klaten. JPDI (Jurnal Pendidikan Dasar Indonesia), 4(2), 34-45. Diambil dari https://journal. stkipsingkawang.ac.id/index.php/JPDI/ article/view/1220

Sakti, B. P. (2019b). Training Writing Nonficial Stories In Students Of The PGSD Study Program Widya Dharma Klaten University. Jurnal Berdaya Mandiri, 1(1), 58-65. https://doi.org/10.31316/ jbm.v1i1.282

Sakti, B. P. (2020a). The Role Of Parents And Teachers In Supervising Primary School Student's Attitude Due To Influence From Technology Based On Industrial Revolution 4.0. Prosiding Seminar Nasional PBSI UPY, 1(1), 179-186. Diambil dari http://prosiding.pbsi.upy. ac.id/index.php/2019/article/view/26

Sakti, B. P. (2020b). Upaya Peningkatan Guru Profesional Dalam Menghadapi Pendidikan Di Era Globalisasi. Attadib: Journal of Elementary Education, 4(1), 74-83. https://doi.org/10.32507/ ATTADIB.V4I1.632

Sakti, B. P., \& Budiyono, S. (2019). Pelaksanaan Pembelajaran Tematik Di SDN 1 Kragilan. Refleksi Edukatika: Jurnal Ilmiah Kependidikan, 10(1), 65-70. Diambil dari https://jurnal.umk. ac.id/index.php/RE/article/view/3860

Siahaya, I. A. (2014). Dampak Penggunaan Email dan Instant Messenger terhadap Komunikasi Organisasi. Jurnal InterAct, 3(1), 55-64. Diambil dari http://ojs. atmajaya.ac.id/index.php/fiabikom/ article/view/718 
Susanto. (2019). Tekankan Data Valid, PAUD dan Dikmas Kota Pekalongan Isi Dapodik Online - Tribun Jateng. Diambil 23 Oktober 2019, dari https:// jateng.tribunnews.com/2018/10/10/ tekankan-data-valid-paud-dan-dikmaskota-pekalongan-isi-dapodik-online

Sutedjo, B., \& Oetomo, D. (2015). Efektivitas Email Untuk Pemasaran. Jurnal Eksplorasi Karya Sistem Informasi dan Sains (Vol. 2). Diambil dari https:// ti.ukdw.ac.id/ojs/index.php/eksis/article/ view/390
Wardani. (2019). Di Negara Ini Kirim Email setelah Jam Kerja Bisa Kena Sanksi - Tekno Liputan6.com. Diambil 21 Oktober 2019, dari https://www. liputan6.com/tekno/read/4088133/dinegara-ini-kirim-email-setelah-jamkerja-bisa-kena-sanksi 